\title{
How Can Temperature Logs Help Identify Permeable Fractures and Define a Conceptual Model of Fluid Circulation? An Example from Deep Geothermal Wells in the Upper Rhine Graben
}

\author{
Jeanne Vidal $\mathbb{D}^{\mathrm{D}}$, Régis Hehn, Carole Glaas $\mathbb{D}^{\mathrm{D}}$, and Albert Genter \\ ES-Géothermie, Bat Le Belem 5 rue de Lisbonne, 67300 Schiltigheim, France \\ Correspondence should be addressed to Jeanne Vidal; jeannevidal@ing.uchile.cl
}

Received 7 November 2018; Revised 25 January 2019; Accepted 19 February 2019; Published 10 July 2019

Guest Editor: Fabrizio Agosta

Copyright (c) 2019 Jeanne Vidal et al. This is an open access article distributed under the Creative Commons Attribution License, which permits unrestricted use, distribution, and reproduction in any medium, provided the original work is properly cited.

\begin{abstract}
Identifying fluid circulation in fracture zones (FZs) is a key challenge in the extraction of deep geothermal heat from natural reservoirs in the Upper Rhine Graben. This study focuses on permeable FZs present within the granitic basement penetrated by deep geothermal well GPK-1 at Soultz and GRT-1 and GRT-2 at Rittershoffen (France). The various temperature (T) log datasets acquired from these wells during production and at equilibrium, with the associated flow logs, allow for the unique opportunity to interpret fluid circulation at the borehole scale. All permeable FZs identified by permeability indicators measured during drilling operations and from image logs spatially coincide with positive or negative $\mathrm{T}$ anomalies observed in the $\mathrm{T}$ logs during production and/or at equilibrium. However, within the FZs, partially open fractures act as narrower paths for circulation at different temperatures. These temperatures can even be estimated with confidence if the associated flow log is available. The polarity of the T anomalies correlates with the state of equilibrium of the well and thus can change over the well history. During production, the temperature of the water inflow through the fractures can be estimated relative to the mixture of water circulating below the fractures. At thermal equilibrium, the water temperature is estimated with respect to the temperature of the surrounding rock formation. Because temperature fluxes and geothermal fluids are intimately linked, $\mathrm{T}$ logs are a useful, reliable, and very sensitive tool to localize the inflow of geothermal water through FZs.
\end{abstract}

\section{Introduction}

In the Upper Rhine Graben (URG), the underground temperature distribution is spatially heterogeneous, and a series of local anomalies with temperatures above $140^{\circ} \mathrm{C}$ at a $2 \mathrm{~km}$ depth are observed at the regional scale [1-4]. These temperature anomalies are interpreted as convective cells circulating along vertical local faults (Figure 1) [2, 5, 6]. Hot upwellings are mainly concentrated around $\mathrm{N}$-S-striking local faults on the western side of the URG. These N-S-striking local faults, which originate in the Paleozoic granitic basement and extend through the sedimentary cover, channelize these deep fluids. Over more than 30 years, 18 deep geothermal wells have targeted these faults in Germany (Landau, Insheim, Bruchsal, and Brühl) and France (Soultz-sous-Forêts, Rittershoffen and, most recently, Illkirch and Vendenheim) (Figure 1) [7-12]. Temperature (T) logs obtained from these wells confirm the presence of hydrothermal convection and assert the roles of faults and fracture zones (FZs) as preferential pathways for geothermal brine [12-15]. The top of the granitic basement, which is highly fractured and affected by hydrothermal alteration, presents a low geothermal gradient associated with the vertical flow of brine and is locally affected by temperature anomalies interpreted as the thermal signatures of the FZs (Figures 2-4) [14-16].

Thus, the characterization of permeable fracture zones that act as primary potential paths for fluid flow is a key challenge for the development of geothermal reservoirs in granitic rocks. Experience shows that the characterization of permeable FZs by flow logs (obtained with a spinner tool) is difficult because flow logs are hard to obtain and interpret in these reservoirs. In contrast, $\mathrm{T}$ logs are cheap and easily acquired. $\mathrm{T}$ anomalies are interpreted as the thermal expressions of permeable FZs in several deep wells in geothermal 


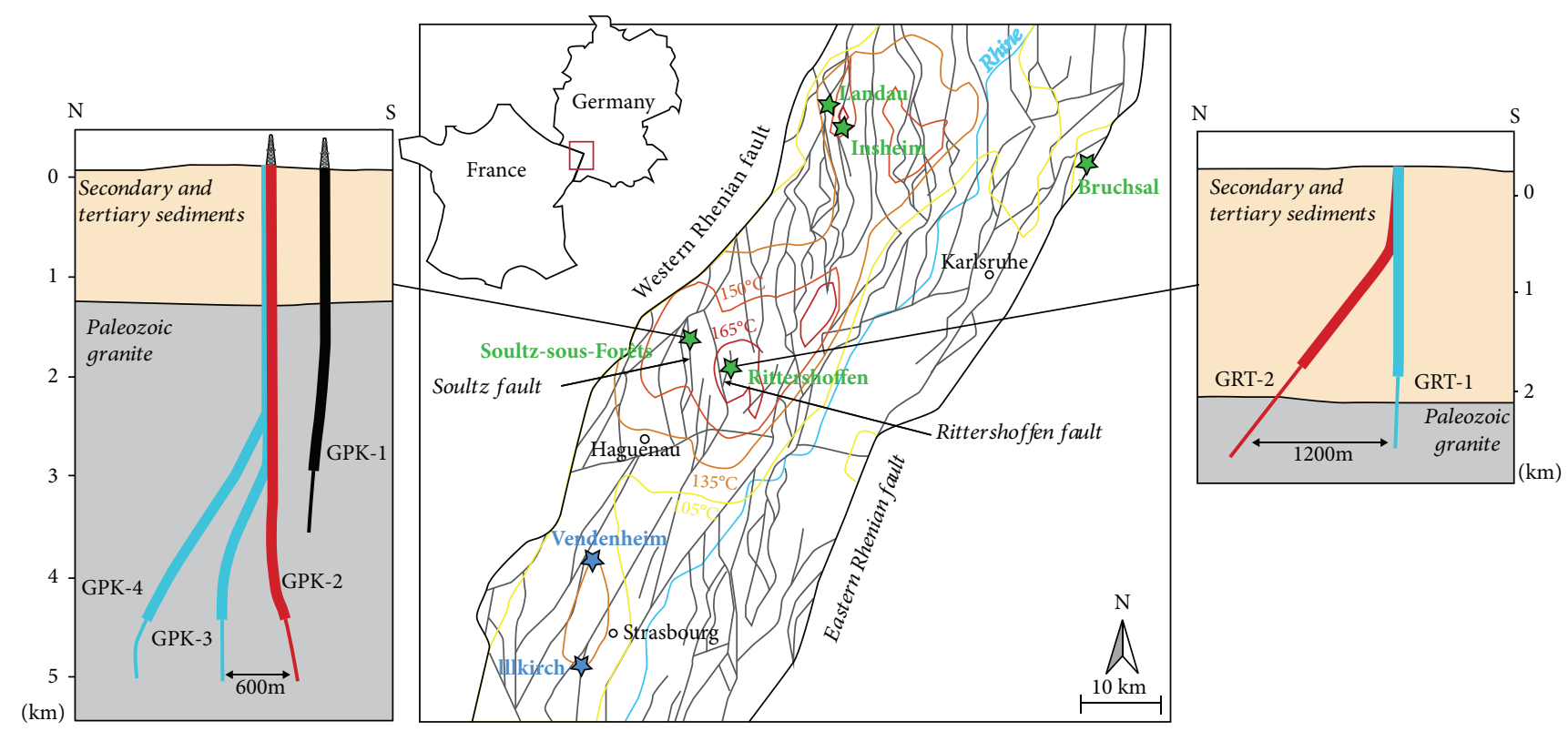

FIGURE 1: Structural map of the center of the Upper Rhine Graben with isotherms at a $2 \mathrm{~km}$ depth from the geoportal GeORG [55]. The geothermal anomaly in the Strasbourg area is from the dataset of Baillieux et al. [1]. Geothermal power plants in operation are represented by green stars, and the geothermal projects under drilling operations are represented by blue stars. On the left: N-S section through the geothermal wells of the Soultz-sous-Forêts power plant with a simplified geology. On the right: N-S section through the geothermal wells of the Rittershoffen power plant with a simplified geology. The thick line represents the casing section of the well, whereas the thin one represents the open hole. Production wells are in red, and injection wells are in blue. The GPK-1 well is represented in black because it is now used as an observation well.

systems worldwide [13, 14, 17-19]. However, in this paper, the datasets of the $\mathrm{T}$ logs acquired from wells at equilibrium and during production, combined with flow logs when they are available, offer a unique chance to further interpret $\mathrm{T}$ logs at the borehole scale. The reinterpretation of $\mathrm{T}$ logs at equilibrium and during production and their comparison with the permeability indicators and structural data from the FZs in well GPK-1 at Soultz and wells GRT-1 and GRT-2 at Rittershoffen provide a new perspective to better understand brine circulation through FZs in the granitic basement.

After a structural analysis of the main permeable fracture network that has channelized geothermal brines at the first order, the attention is focused on a comparison of $\mathrm{T} \operatorname{logs}$ obtained at equilibrium and during production with flow logs if they are available from the wells. Finally, a conceptual model of fluid circulations through the FZs and the associated $\mathrm{T}$ anomalies is proposed at the borehole scale.

\section{Soultz and Rittershoffen Geothermal Sites}

Both projects exploit the hot upwelling of geothermal brine concentrated around the Soultz and the Rittershoffen faults (Figure 1). Extensive studies have identified convection associated with these hot upwellings; these studies have used numerical models on both the regional scale $[4,20]$ and local scale [21]. The role of faults as preferential fluid pathways is evident in other geothermal systems [22-25].

The pilot project of Soultz-sous-Forêts was initiated in the late 1980s. The target of the project was the development, hydraulic testing, and modeling of two Enhanced Geothermal System (EGS) heat exchangers within the granitic basement at depths of 3.5 and $5 \mathrm{~km}[15,26,27]$. In 1987, exploration well GPK- 1 was drilled to a depth of $2 \mathrm{~km}$ and extended to a depth of $3.6 \mathrm{~km}$ in 1992 after hydraulic stimulation (Figure 1). At Soultz, geothermal water was pumped from the production well (GPK-2) and reinjected at a lower temperature into the injection wells (GPK-3 and GPK-4) after delivering geothermal energy through a heat exchanger to a binary power plant [10].

The geothermal project in Rittershoffen was initiated in 2008 and advised by lessons learned in Soultz. It is located less than $10 \mathrm{~km}$ east of Soultz (Figure 1). Injection well GRT-1 was drilled to a depth of $2.5 \mathrm{~km}$ in 2012 and thermally, chemically, and hydraulically stimulated in 2013. Production well GRT-2 was drilled to a depth of $2.5 \mathrm{~km}$ and is highly deviated accordingly to the geometry of the Rittershoffen fault (Figure 1). Well GRT-2 was not stimulated and thus, is defined as an hydrothermal well. The geothermal reservoir is mainly located in the granitic basement.

Geochemical studies indicate that the same brine is circulating within the large-scale fractured reservoir between Soultz and Rittershoffen [28, 29]. The reservoir was thoroughly investigated with a large amount of data (obtained from core samples, image logs, geophysical logs, microseismic data, vertical seismic profile, seismic reflection, etc.); these data were used to develop structural models of the multiscale fracture network associated with the Soultz and Rittershoffen faults $[13,30-33]$ as well as models of hydraulic circulation [34].

At the borehole scale, structural information from the granitic basement indicates that the highest density of fractures occurs in the first hundred meters of the 
GPK-1

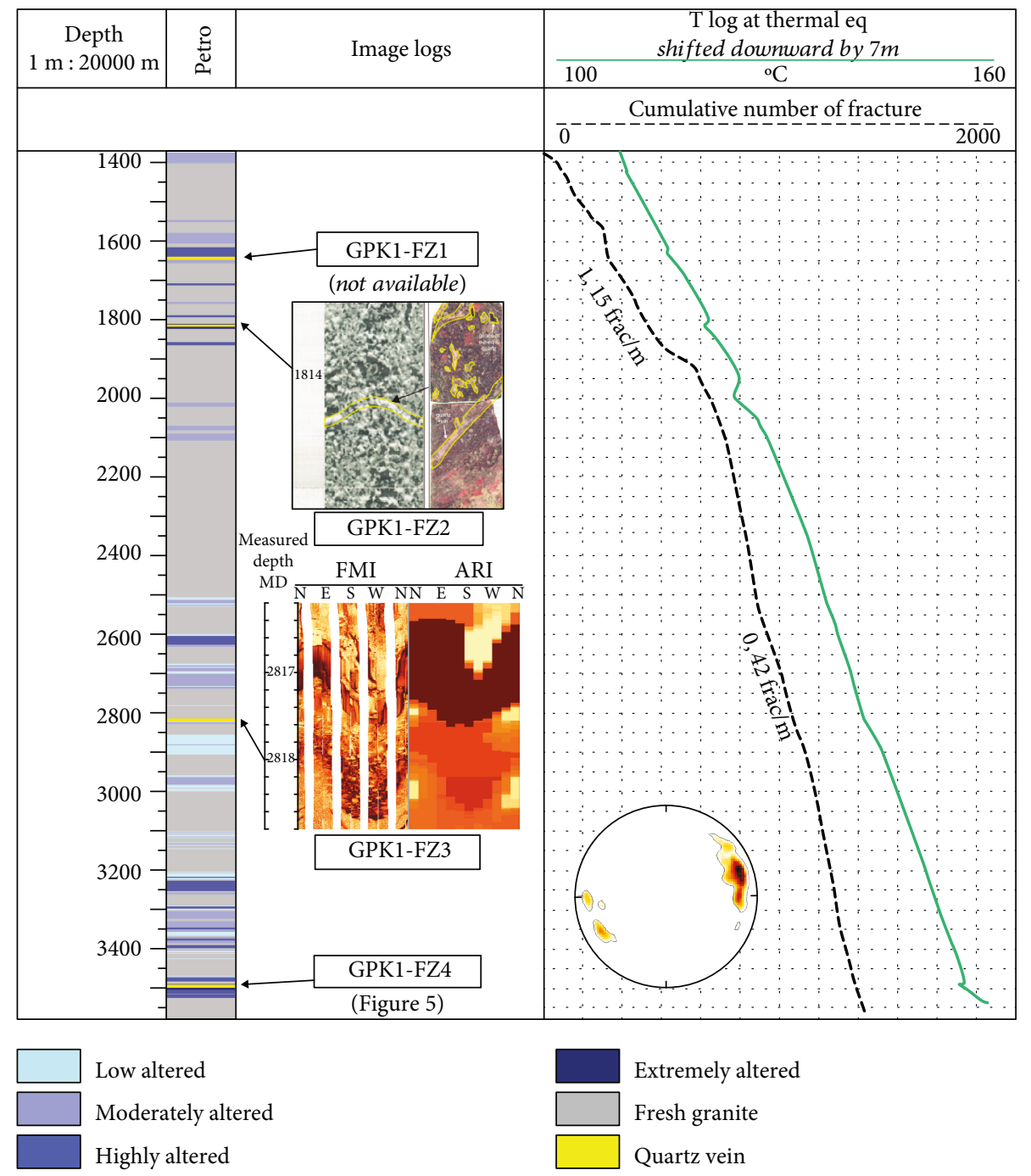

FIgURE 2: T logs from the granitic basement at thermal equilibrium in GPK-1 (Mar 1993, five months after the last hydraulic tests). T anomalies are associated with the permeable FZs observed in the image logs. The structural data of these FZs are presented in Table 1. Depth is expressed in Measured Depth (MD). T logs and flow logs were shifted manually to fit the anomalies with the fracture zones. Petrographic results are from Genter and Traineau [38]. Schmidt diagrams (lower hemisphere) and the cumulative number of fractures in the granitic basement are from Genter et al. [35].

hydrothermally altered granite. Data from acoustic image logs indicate values of $1,15 \mathrm{frac} / \mathrm{m}$ in GPK-1 in the first $500 \mathrm{~m}$ (data from a BoreHole TeleViewer, [35]) (Figure 2), $1,15 \mathrm{frac} / \mathrm{m}$ in GRT-1 in the first $200 \mathrm{~m}$ (Figure 3), and 0,75 $\mathrm{frac} / \mathrm{m}$ in the deviated well GRT-2 (data from ultrasonic borehole images, [36]) (Figure 4). The fractures are mainly oriented NNW-SSE, with a steep dip mainly westward in GPK-1 (data from BHTV, [35]). In well GRT-1, the fractures strike mainly $\mathrm{N} 10^{\circ} \mathrm{E}$ and dip approximately $60^{\circ} \mathrm{W}$, whereas they are more scattered in GRT-2, with the main set oriented $\mathrm{N} 160^{\circ}$ to $\mathrm{N}-\mathrm{S}$ and dipping $60^{\circ} \mathrm{W}$ (data from UBI, [36]). Hydraulic tests in GPK-1 indicate that $95 \%$ of the fluid flow enters the rock mass at only 10 discrete flow points [14]. These tests are consistent with cores from the permeable FZ, where a high density of partially open fractures promotes fluid circulation. These partially open fractures are centimeters thick and are mainly filled by geodic quartz $[37,38]$. An investigation of a quartz vein in the exploration borehole EPS-1 revealed at least seven generations of quartz, indicating a pulsed system of circulation [39]. Surrounding the core is a damage zone, with a width that ranges from centimeters to tens of meters. In this altered and porous zone, primary minerals are partly dissolved, and illite precipitation dominates the granite matrix [38, 40]. The degrees of alteration in the granite were determined based on the observations of the illitization amount in the core samples or cuttings [37, 41-43].

These permeable FZs mainly intersected in the granitic section, which is dominated by low temperature gradients associated with convection. The $\mathrm{T}$ gradients are approximately $20^{\circ} \mathrm{C} / \mathrm{km}$ in GPK-1, nearly in GRT-1, and $18^{\circ} \mathrm{C} / \mathrm{km}$ in GRT-2 (Figures 2-4). All permeable FZs have T anomalies 
GRT-1

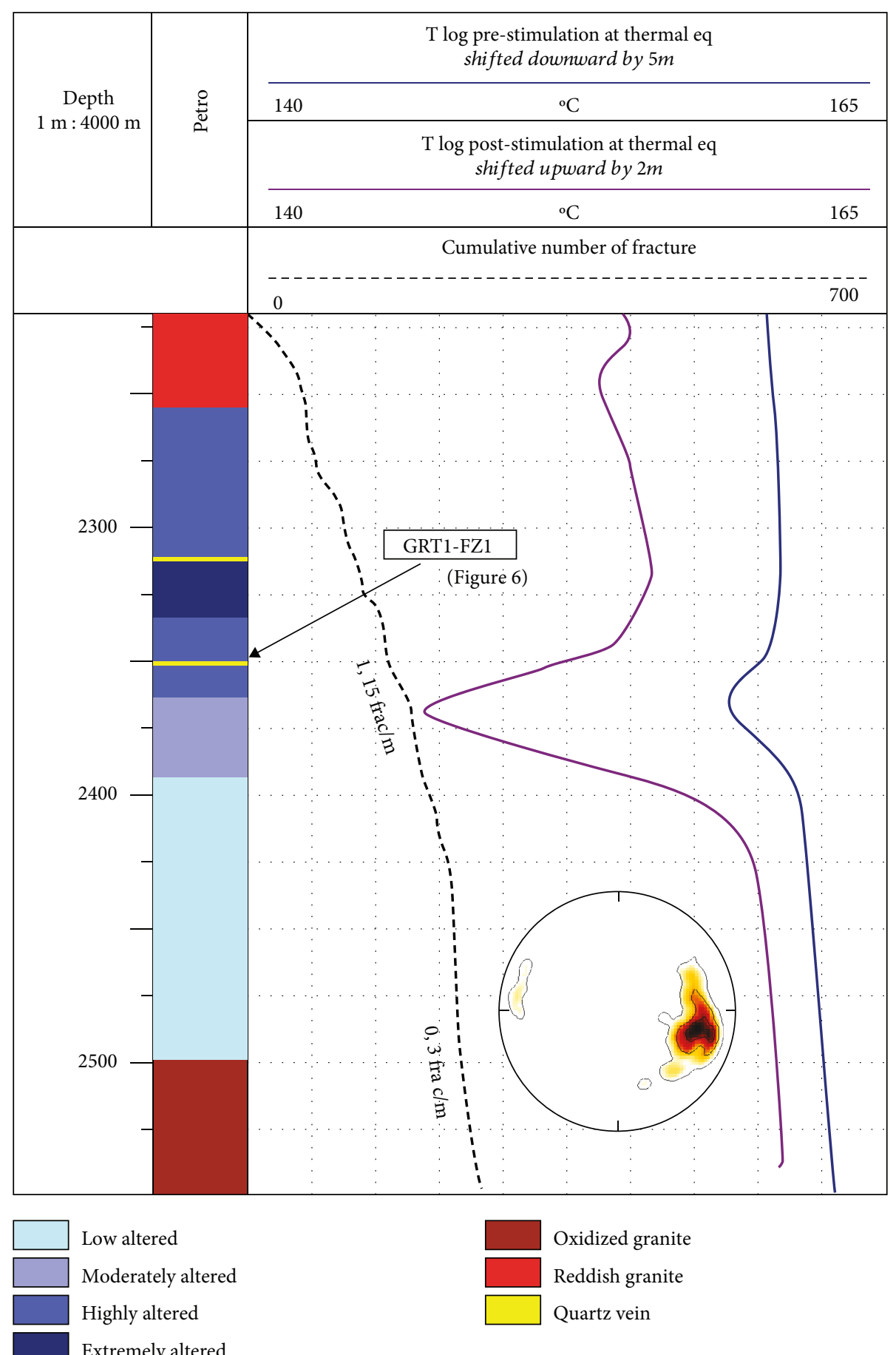

FIGURE 3: T logs from the granitic basement at thermal equilibrium in GRT-1 prestimulation (Apr 2013, four months after hydraulic tests) and poststimulation (Dec 2013, five months after hydraulic stimulation). T anomalies are associated with the permeable FZs observed in the image logs. The structural data of these FZs are presented in Table 1. Depth is expressed in Measured Depth (MD). T logs and flow logs were shifted manually to fit the anomalies with the fracture zones. Petrographic results are from Vidal et al. [44] and Glaas et al. [41]. Schmidt diagrams (lower hemisphere) and the cumulative number of fractures in the granitic basement are from Vidal et al. [36].

that spatially correlate with null observations in the $\mathrm{T}$ logs (Figures 2-4) [13-16]. Negative $\mathrm{T}$ anomalies are interpreted as the remnant cooling of porous damage zones after mud invasions during drilling operations and water injection during stimulation operations [15]. However, is this interpretation still true several months after drilling operations and hydraulic tests, when the well is at thermal equilibrium? Could we propose another interpretation based on the 
GRT-2

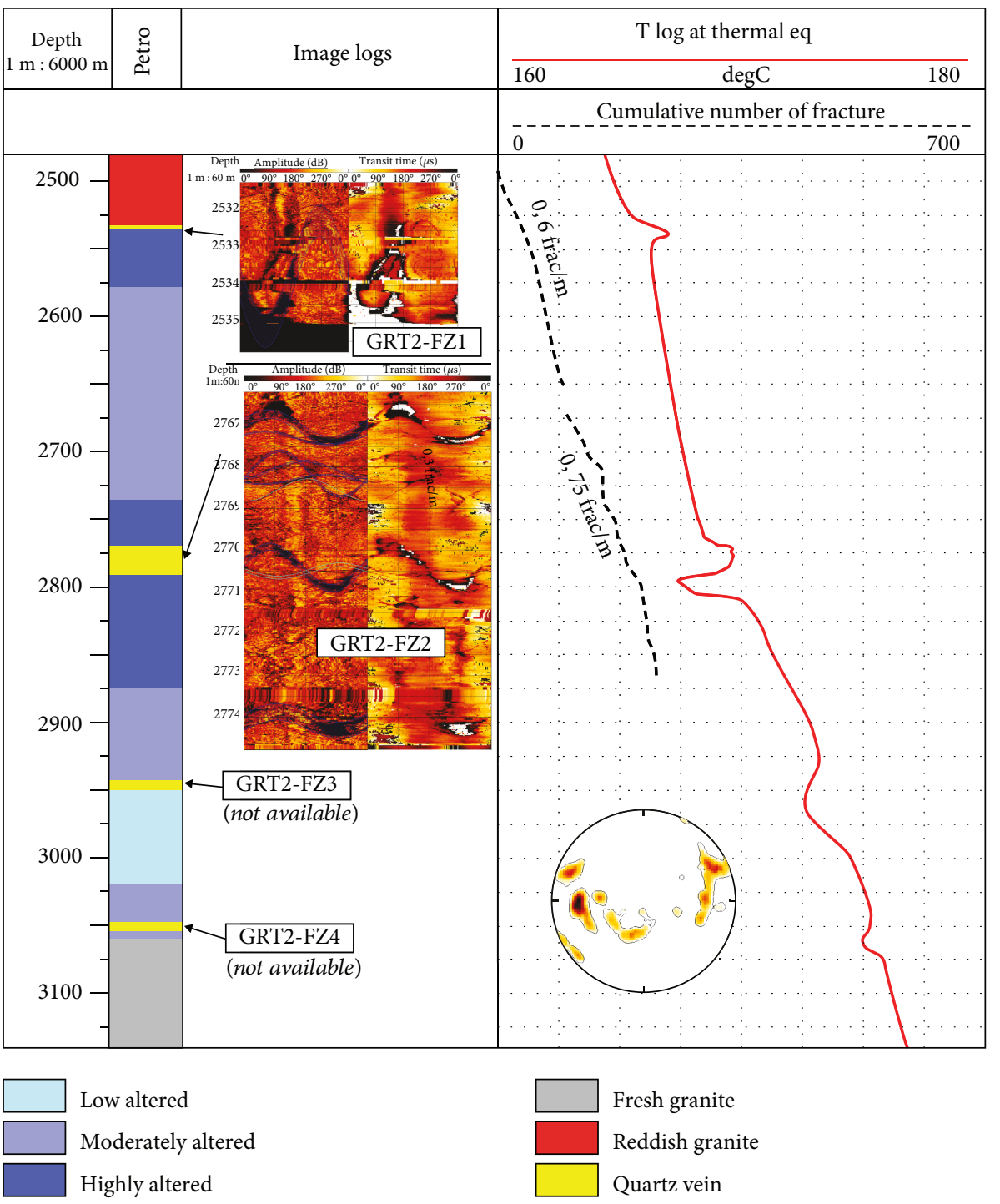

FIGURE 4: T logs from the granitic basement at thermal equilibrium in GRT-2 (September 2014, one month after drilling). T anomalies are associated with the permeable FZs observed in the image logs. The structural data of these FZs are presented in Table 1. Depth is expressed in Measured Depth (MD). T logs and flow logs were shifted manually to fit the anomalies with the fracture zones. Petrographic results are from Vidal et al. [44] and Glaas et al. [41]. Schmidt diagrams (lower hemisphere) and the cumulative number of fractures in the granitic basement are from Vidal et al. [36].

internal organization of the FZs? Is the intensity of the anomaly linked with the degree of permeability of the FZs? How could we explain the polarity and variations in the intensity of $\mathrm{T}$ anomalies over time?

\section{Materials and Methods}

3.1. Permeable FZs from Mud Logs and Image Logs. FZs that correspond to clusters of fractures partially open at the borehole scale and surrounded by a halo of hydrothermal alteration were identified in previous studies in Soultz and Rittershoffen [16, 44]. The core of the FZ is composed of opened fractures and quartz veins, and the damage zone is composed of illitic minerals [38]. Other secondary minerals could be present (carbonates, sulfates, sulfides, and Fe-oxides).

Permeable FZs were identified using permeability indicators from several mud logs as follows:

(i) Drilling mud losses and brine outflow are linked to permeable FZs [13-15, 33, 38, 45, 46]

(ii) The occurrence of alkanes, as well as other gases such as helium, $\mathrm{CO}_{2}$, and radon, indicates permeable fracture zones $[47,48]$

(iii) The mineralogical investigation of rock cuttings or core samples, when available, is an efficient method for identifying hydrothermally altered zones in the 
granite $[13,49]$. Brine circulation through a permeable fracture zone leads to partial sealing by secondary geodic quartz and clay mineral deposits, which are easily detectable in cuttings by visual inspection and in the laboratory by XRD $[39,40,43,50]$. When cuttings are not available or reliable, gamma ray (GR) logging, which measures natural radioactivity, is a good indicator of hydrothermal alteration [42]. In GR, the occurrence of geodic quartz is associated with sharp localized negative anomalies, whereas clay minerals, which are K-bearing minerals, are associated with positive anomalies that can extend several meters

Finally, once the permeability indicators are identified, acoustic image logs allow for the identification of the geometry of the FZs and the acoustic aperture of the fractures at the borehole scale.

3.2. $T$ Logs and Flow Logs. The $\mathrm{T}$ anomalies observed in a temperature profile are considered the most reliable of the permeability indicators $[14,16,18,24]$. $T$ logs can be acquired at thermal equilibrium, i.e., after several weeks without well operations, or during production. When T logs are acquired during production, a flow log can also be acquired, and the flow is measured based on the speed of the rotation of the helix (spinner tool). $\mathrm{T}$ logs acquired at equilibrium are acquired downward; $\mathrm{T}$ logs and flow logs acquired during production are acquired upward. $\mathrm{T}$ logs acquired during production allow for temperature estimation of the water circulating into the fracture zone with the following equation (assuming a first-order approximation) (Figure 5):

$$
T_{r} \times Q_{r}+T_{f} \times Q_{f}=T_{m} \times Q_{m}
$$

where $T_{r}$ is the temperature of the water coming from below the fracture, $Q_{r}$ is the flowrate of the water coming from below the fracture, $T_{f}$ is the temperature of the water coming from the fracture, $Q_{f}$ is the flowrate of the water coming from the fracture, $T_{m}$ is the temperature of the mix of water above the fracture, and $Q_{m}$ is the flowrate of the mix of water above the fracture.

At equilibrium, $\mathrm{T}$ anomalies were identified primarily with $\mathrm{T}$ logs acquired before stimulation (Figures 2-4). Thermal equilibrium must not be influenced by cold mud or cold water stored in fractures after drilling and hydraulic operations. Poststimulation T logs were compared to prestimulation $\mathrm{T}$ logs. It is possible to observe some vertical depth shifts between $\mathrm{T}$ anomalies and fracture zones from core samples and image logs. These shifts could have several explanations. All logs were not acquired at the same time, and the process of depth matching among all logs is complicated. Moreover, temperature variations led to cable elongations that were not corrected for the well-logging data. The logs were shifted downward or upward based on the depths of the main open fractures observed in the acoustic logs.

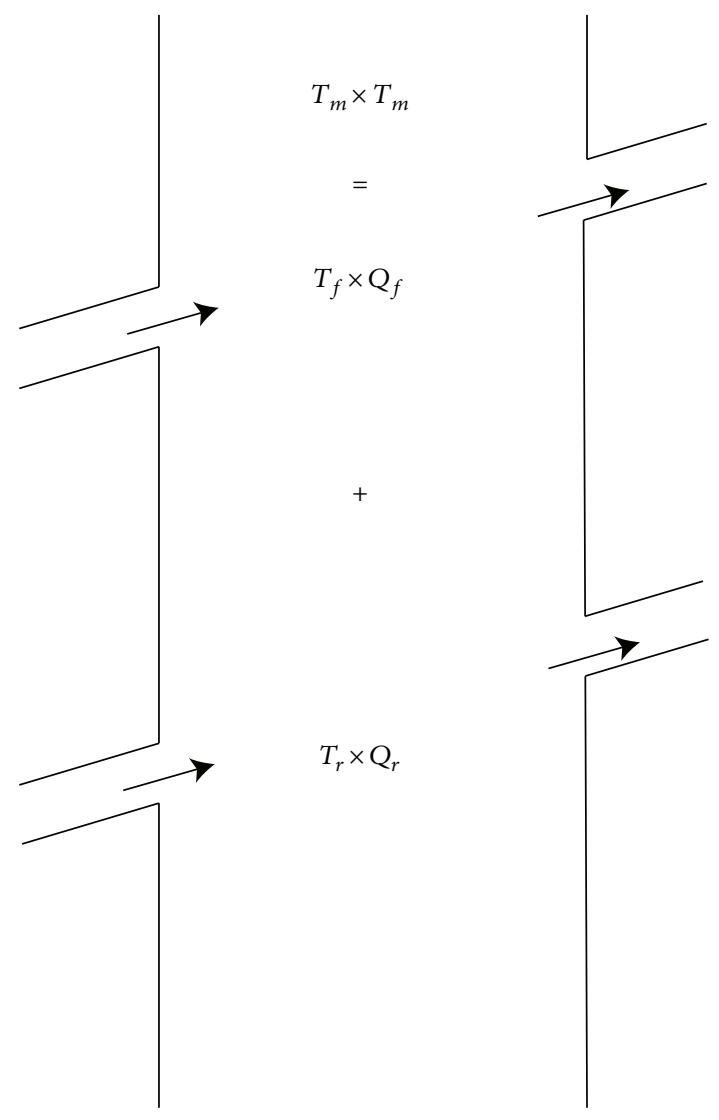

FIgURE 5: Scheme of the mixture of fluids coming from fractures into a permeable FZ.

\section{Results}

4.1. Permeable FZs from $T$ Logs at Thermal Equilibrium. Four permeable FZs are identified in GPK-1, and they are all associated with negative thermal anomalies at thermal equilibrium (Table 1 and Figure 2). The borehole images of GPK1-FZ2 and GPK1-FZ3 are available in Vidal et al. [16, $43,44]$. Another negative anomaly is visible at a depth of $2100 \mathrm{~m}$, but based on hydraulic tests, the FZ was identified as permeable after stimulation [51].

In GRT-1, one FZ was identified as permeable after stimulation and is associated with a negative anomaly at thermal equilibrium (Table 1 and Figure 3). GRT1-FZ1 includes the two permeable fractures observed in the granitic basement, as described in Vidal et al. [16]. A poststimulation anomaly is observed in the $\mathrm{T} \log$ at $2236 \mathrm{~m} \mathrm{MD}$, but it is not spatially correlated with permeability indicators obtained before stimulation. Four permeable FZs are identified in GRT-2; two are associated with positive anomalies (GRT2-FZ1 and GRT2-FZ2), and two are associated with negative anomalies (GRT2-FZ3 and GRT2-FZ4) (Figure 4). GRT2-FZ1 includes the two uppermost permeable fractures observed in the table 1 of Vidal et al. [16], and GRT2-FZ2 includes the five deepest fractures. The borehole images of GRT-1 and GRT-2 are available in Vidal et al. [16].

Permeable fractures are mainly oriented $\mathrm{N} 170^{\circ} \mathrm{E}$ and dip westward (Figure 6). Fractures that dip westward are associated with positive or negative $\mathrm{T}$ anomalies. Fractures that dip 
TABLE 1: Temperature anomalies in well GPK-1 in Soultz and GRT1 and GRT-2 in Rittershoffen. Structural data from the main open fractures in the FZs, as well as the polarity and depth of the anomalies, are presented. Structural data in italics indicate that acoustic images are not available. For GRT-2, values are calculated from oriented calipers [41].

\begin{tabular}{lccccc}
\hline & \multicolumn{3}{c}{ Main open fracture } & \multicolumn{2}{c}{ Temperature } \\
Name & $\mathrm{MD}$ & Strike & Dip & $\mathrm{MD}$ & Signal \\
& $\mathrm{m}$ & Deg & Def & $\mathrm{m}$ & \\
\hline GPK1-FZ1 & 1645 & $\mathrm{~N} 155^{\circ} \mathrm{E}$ & $76^{\circ} \mathrm{W}$ & 1623 & - \\
GPK1-FZ2 & 1814 & $\mathrm{~N} 120^{\circ} \mathrm{E}$ & $47^{\circ} \mathrm{E}$ & 1815 & - \\
& 2817 & $\mathrm{~N} 150^{\circ} \mathrm{E}$ & $75^{\circ} \mathrm{W}$ & 2818 & - \\
GPK1-FZ3 & 2818.5 & $\mathrm{~N} 140^{\circ} \mathrm{E}$ & $70^{\circ} \mathrm{X}$ & & \\
& 3489 & $\mathrm{~N} 160^{\circ} \mathrm{E}$ & $60^{\circ} \mathrm{W}$ & 3495 & - \\
GPK1-FZ4 & 3496 & $\mathrm{~N} 170^{\circ} \mathrm{E}$ & $70^{\circ} \mathrm{W}$ & & \\
& 2328 & $\mathrm{~N} 20^{\circ} \mathrm{E}$ & $50^{\circ} \mathrm{W}$ & 2380 & - \\
GRT1-FZ1 & 2368 & $\mathrm{~N} 170^{\circ} \mathrm{E}$ & $55^{\circ} \mathrm{W}$ & & \\
& 2534 & $\mathrm{~N} 00^{\circ} \mathrm{E}$ & $80^{\circ} \mathrm{E}$ & 2537 & + \\
GRT2-FZ1 & 2540 & $\mathrm{~N} 10^{\circ} \mathrm{E}$ & $72^{\circ} \mathrm{E}$ & & \\
& 2767 & $\mathrm{~N} 154^{\circ} \mathrm{E}$ & $83^{\circ} \mathrm{W}$ & & \\
& 2770.5 & $\mathrm{~N} 160^{\circ} \mathrm{E}$ & $87^{\circ} \mathrm{W}$ & & \\
GRT2-FZ2 & 2774 & $\mathrm{~N} 170^{\circ} \mathrm{E}$ & $64^{\circ} \mathrm{W}$ & 2775 & + \\
& 2787 & $\mathrm{~N} 45^{\circ} \mathrm{E}$ & $57^{\circ} \mathrm{E}$ & & \\
& 2788 & $\mathrm{~N} 00^{\circ} \mathrm{E}$ & $55^{\circ} \mathrm{W}$ & & - \\
GRT2-FZ3 & 2950 & $\mathrm{~N} 170^{\circ} \mathrm{E}$ & $90^{\circ} \mathrm{E}$ & 2970 & - \\
GRT2-FZ4 & 3050 & $\mathrm{~N} 00^{\circ} \mathrm{E}$ & $70^{\circ} \mathrm{W}$ & 3060 & - \\
\hline
\end{tabular}

eastward are also associated with $\mathrm{T}$ anomalies that are positive or negative. The polarity of $\mathrm{T}$ anomalies is not directly linked to the fracture orientation or the dip direction. Thus, it is not possible to anticipate the polarity of the anomalies with respect to the fracture geometry.

\subsection{Fluid Circulation from $T$ Logs during Production}

4.2.1. GPK-1. The permeable FZ in GPK1-FZ4 is presented in Figure 7. In September 1996, during production at $10.8 \mathrm{~L} / \mathrm{s}$, a flow $\log$ and a $\mathrm{T} \log$ were acquired. The first inflow of water into the well was observed at $3496 \mathrm{~m} \mathrm{MD}$, with a measured flow of $1.5 \mathrm{~L} / \mathrm{s}$. This inflow depth corresponds with a negative $\mathrm{T}$ anomaly $\left(148^{\circ} \mathrm{C}\right)$ in the $\mathrm{T}$ logs acquired during production. These anomalies are spatially correlated with an open fracture, which is visible in the acoustic image log, striking $\mathrm{N} 170^{\circ} \mathrm{E}$ and dipping westward $70^{\circ}$ at $3496 \mathrm{~m} \mathrm{MD}$. Then, several small positive anomalies are observed and associated with a flow increase at the same depth as the open fracture, striking $\mathrm{N} 160^{\circ} \mathrm{E}$ and dipping $60^{\circ} \mathrm{W}$ at $3489 \mathrm{~m} \mathrm{MD}$. All of these small anomalies are assumed to originate from the same fracture. Above this, the flow is $2.7 \mathrm{~L} / \mathrm{s}$, and the measured temperature is $149^{\circ} \mathrm{C}$. Following the equation described in Section 3.2, the temperature of the water that arrives in this major fracture is approximately $150^{\circ} \mathrm{C}$ :

$$
\frac{149 \times 2.7-148 \times 1.5}{(2.7-1.5)}=150.2
$$

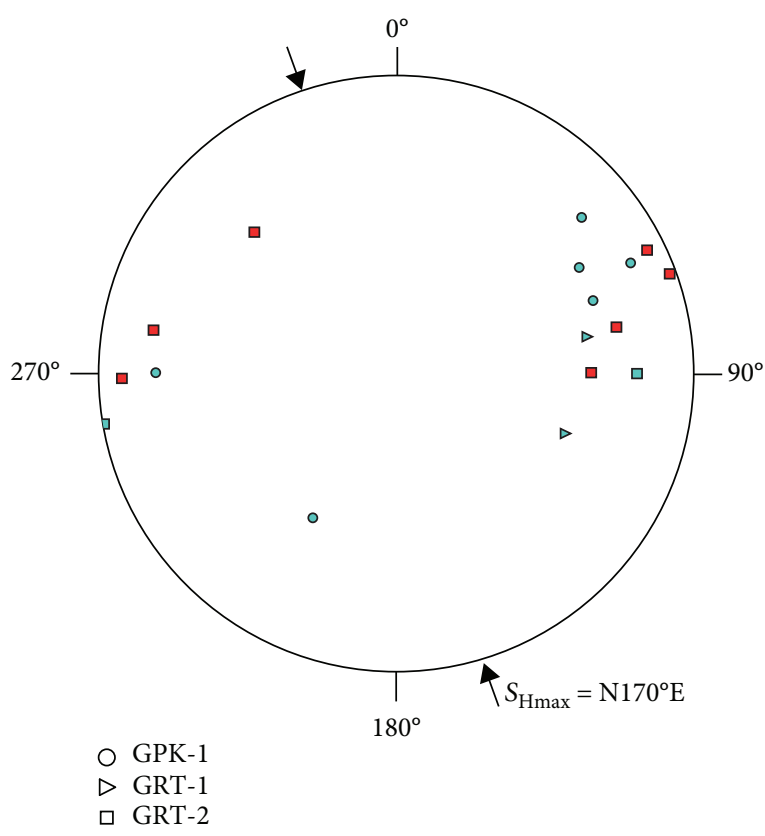

FIgURE 6: Stereoplot of the permeable fractures identified in acoustic image logs from GPK-1 (circle), GRT-1 (triangle), and GRT-2 (square). Blue symbols indicate fractures associated with negative anomalies, and red symbols indicate positive anomalies. Orientations and dips are detailed in Table 1. The maximum horizontal stress is from [56] for Soultz and from [57] for Rittershoffen

At equilibrium (five months after the hydraulic tests), the water inflow through GPK1-FZ4 is associated with a negative anomaly in the T log acquired in March 1993.

The subsequent T logs acquired from well GPK-1 during production are more affected by hydraulic circulation than the other wells and thus are less reliable.

4.2.2. GRT-1. In GRT-1, during hydraulic tests in January 2013, a T log and a flow log were acquired during airlift production at $12,3 \mathrm{~L} / \mathrm{s}$. However, the flow log is not entirely useful; anomalies are observed but are barely quantifiable. T logs at equilibrium were acquired pre- and poststimulation in April and December of 2013, respectively (Figure 8).

In the production $\mathrm{T} \log$, a small negative anomaly is observed at $2233 \mathrm{~m} \mathrm{MD}$, which is not correlated with the flow anomaly (Figure 8(a)). This $\mathrm{T}$ anomaly is not observed in the prestimulation $\mathrm{T} \log$ at thermal equilibrium. However, a $\mathrm{T}$ anomaly is observed in the poststimulation $\mathrm{T} \log$ at $2235.5 \mathrm{~m} \mathrm{MD}$. This anomaly corresponds with an open fracture striking $\mathrm{N} 180^{\circ} \mathrm{E}$ and dipping $60^{\circ}$ westward at $2236.5 \mathrm{~m} \mathrm{MD}$.

The main permeable FZ of GRT1-FZ1 extends from 2325 to $2368 \mathrm{~m}$ MD. Two major open fractures associated with mud losses were also identified. The first one, which is found at the top of the $\mathrm{FZ}$, strikes $\mathrm{N} 20^{\circ} \mathrm{E}$ and dips $50^{\circ}$ westward and is located at $2326 \mathrm{~m} \mathrm{MD} \mathrm{[16].} \mathrm{Although} \mathrm{mud}$ losses were observed during drilling operations, no $\mathrm{T}$ anomaly was observed during production at this depth. A small negative anomaly is observed in the poststimulation $\mathrm{T} \log$ (Figure 3). 


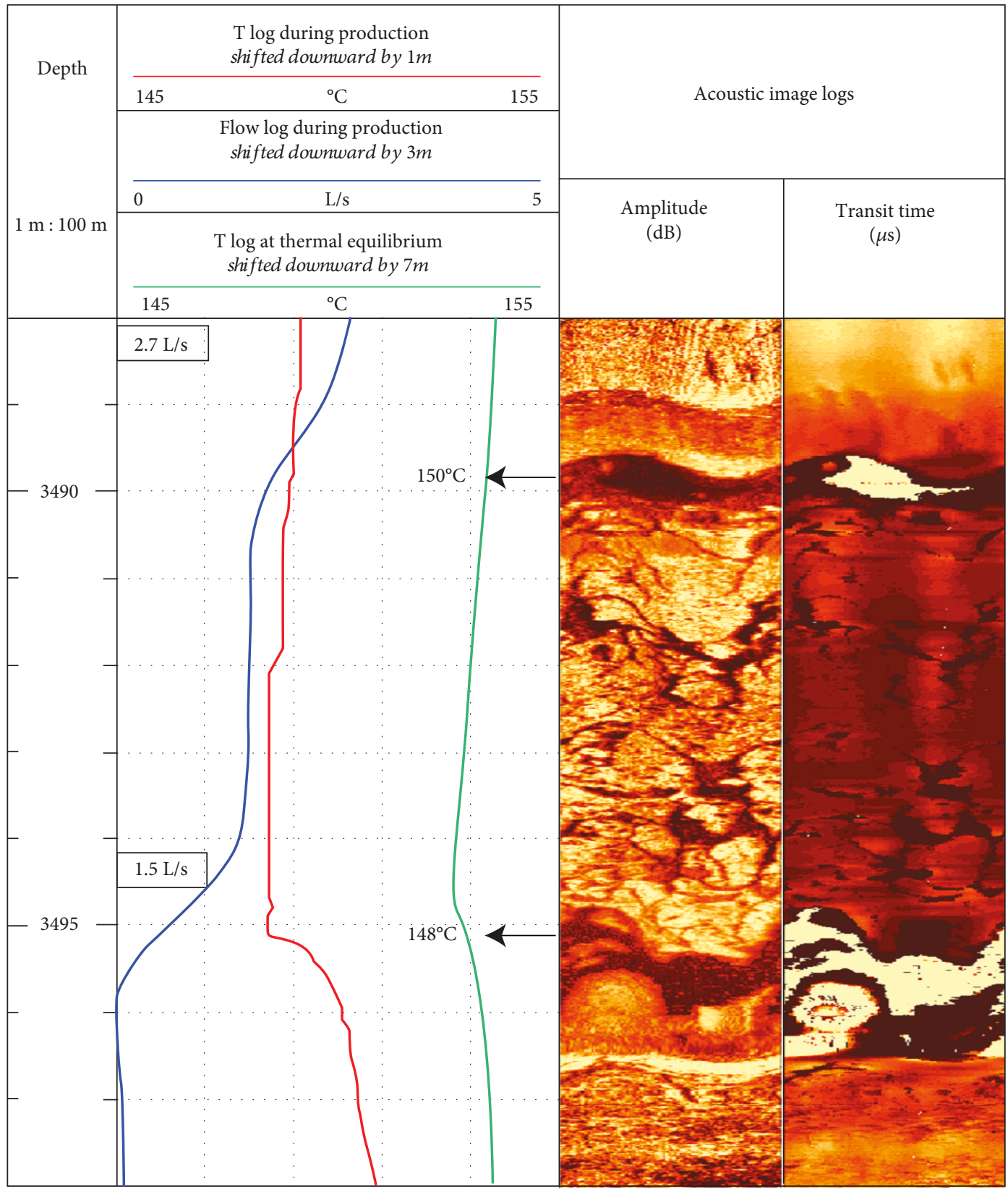

FIGURE 7: T logs from well GPK-1 at thermal equilibrium (Mar 1993, five months after the last hydraulic tests) and during production, with the corresponding flow $\log$ (Sept 1996, production test at $11 \mathrm{~L} / \mathrm{s}$ ). T and flow anomalies are associated with the open fractures observed in the acoustic image logs at 3490 and $3495 \mathrm{~m} \mathrm{MD}$, respectively. Arrows indicate inflows of geothermal water through the fractures. Depth is expressed in MD. The T logs and flow logs were shifted manually to fit the anomalies with fracture zones in all wells.

In the production $\mathrm{T} \log$, a small negative anomaly is observed at $2341 \mathrm{~m} \mathrm{MD}$ that is not correlated with a flow anomaly (Figure $8(\mathrm{~b})$ ). This $\mathrm{T}$ anomaly is incorporated into a larger anomaly evident in the prestimulation $\mathrm{T} \log$ at thermal equilibrium and in the poststimulation $\mathrm{T} \log$ (Figure 3). These anomalies correlate with an open fracture striking $\mathrm{N} 25^{\circ} \mathrm{E}$ and dipping $60^{\circ}$ westward at $2345 \mathrm{~m} \mathrm{MD}$ (Figure 8(b)).

The second open fracture of GRT1-FZ1 is associated with mud losses and is located at $2368 \mathrm{~m} \mathrm{MD}$. It is striking $\mathrm{N} 175^{\circ} \mathrm{E}$ and dipping $65^{\circ}$ westward. This fracture controls $2 / 3$ of the total flowrate and is at the interface between highly altered and fractured granite above and low altered granite below [16]. Thus, this fracture permits the first inflow of water into the well. Surprisingly, the flow log is not consistent with this observation and is thus considered unreliable for the evaluation of the absolute flow associated with the fractures in the well. The flow anomaly is associated with a $\mathrm{T}$ anomaly $\left(+3^{\circ} \mathrm{C}\right)$ at $2364 \mathrm{~m} \mathrm{MD}$ (Figure $\left.8(\mathrm{c})\right)$. A second $\mathrm{T}$ anomaly $\left(+5^{\circ} \mathrm{C}\right)$ at $2350 \mathrm{~m} \mathrm{MD}$ is observed. This positive $\mathrm{T}$ anomaly is not clearly associated with an open fracture but is associated with a cluster of thin fractures. However, the calculation of the water temperature at this depth is not possible because the flow log is not reliable. At equilibrium, 


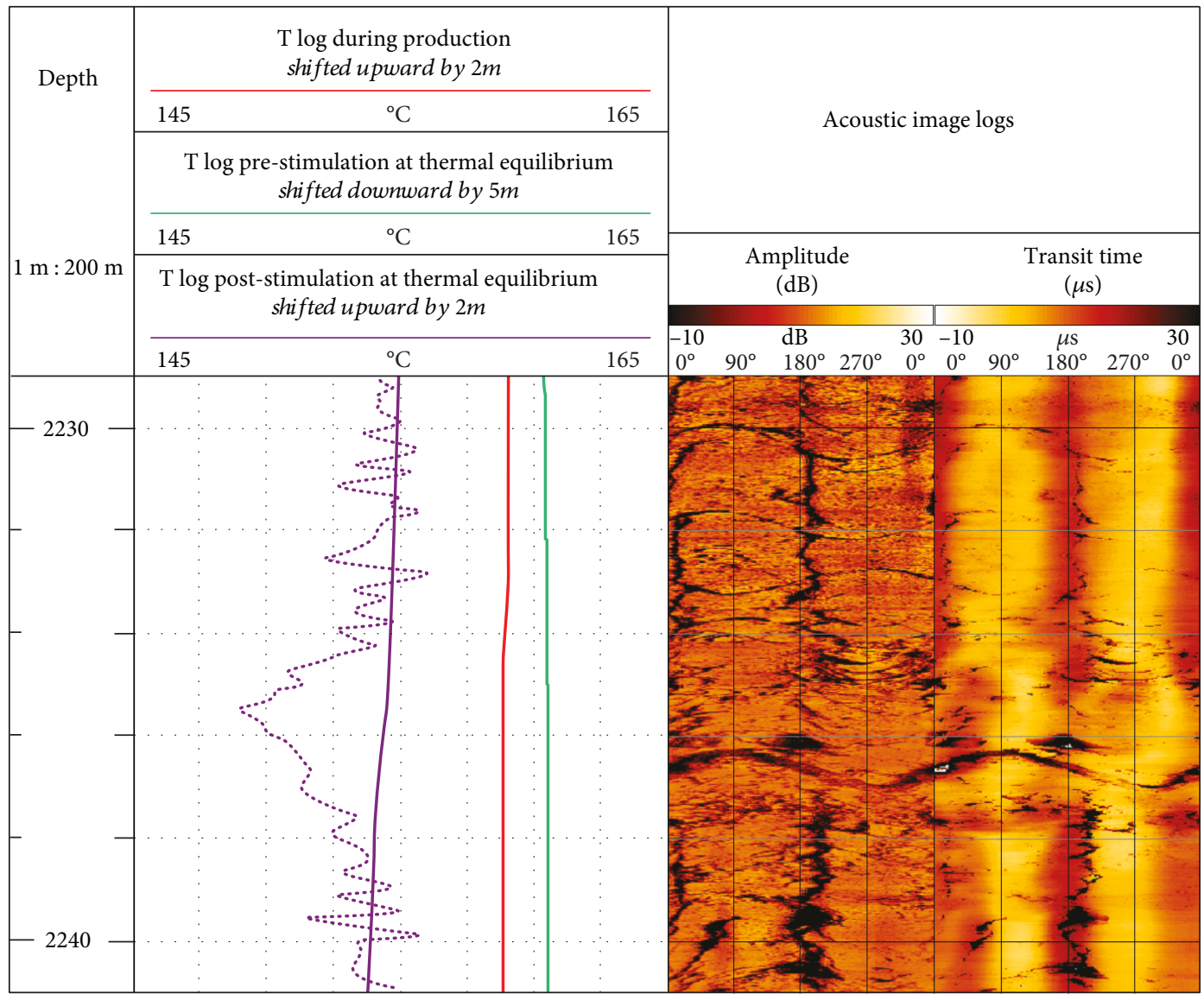

(a)

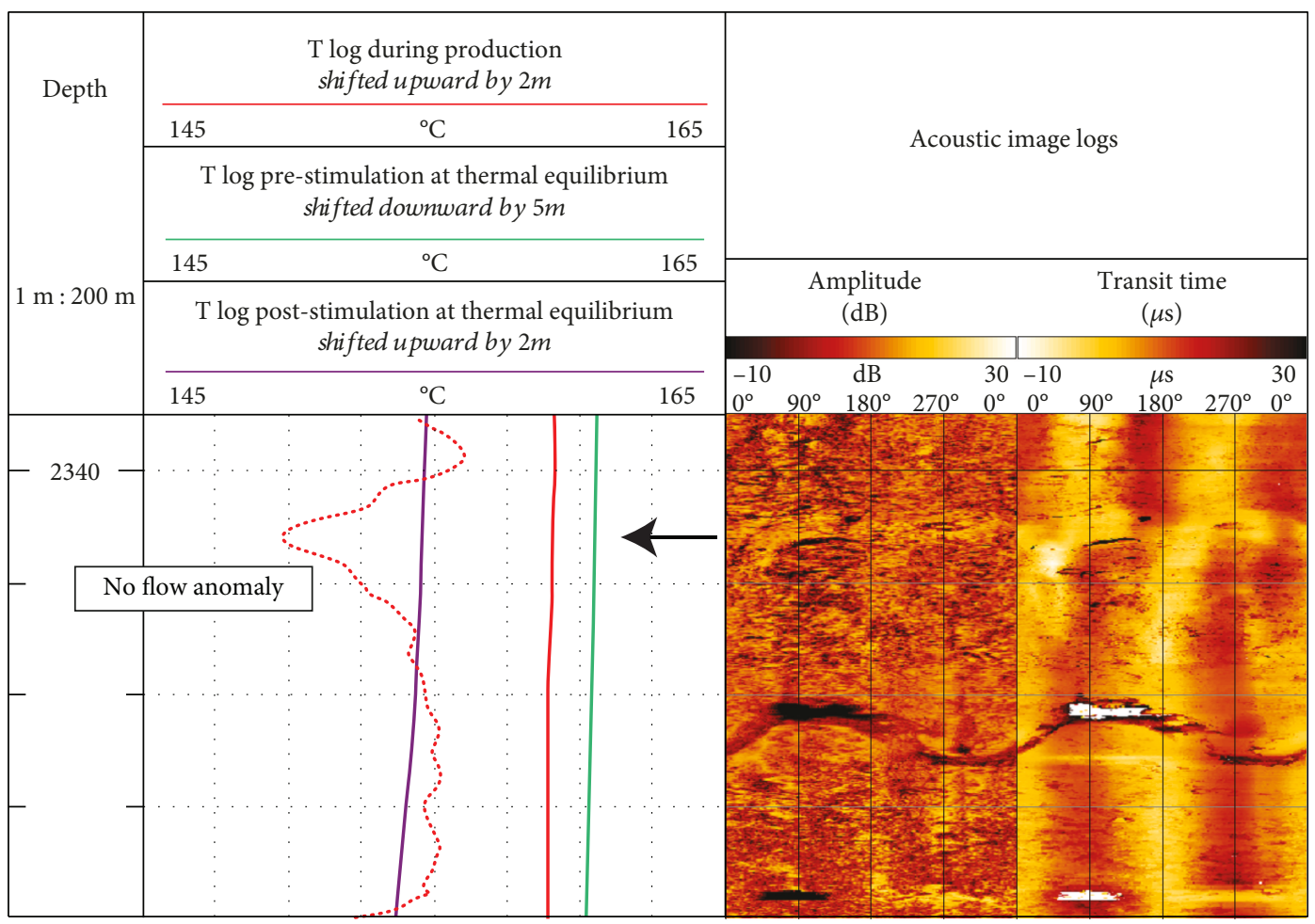

(b)

FIgURe 8: Continued. 


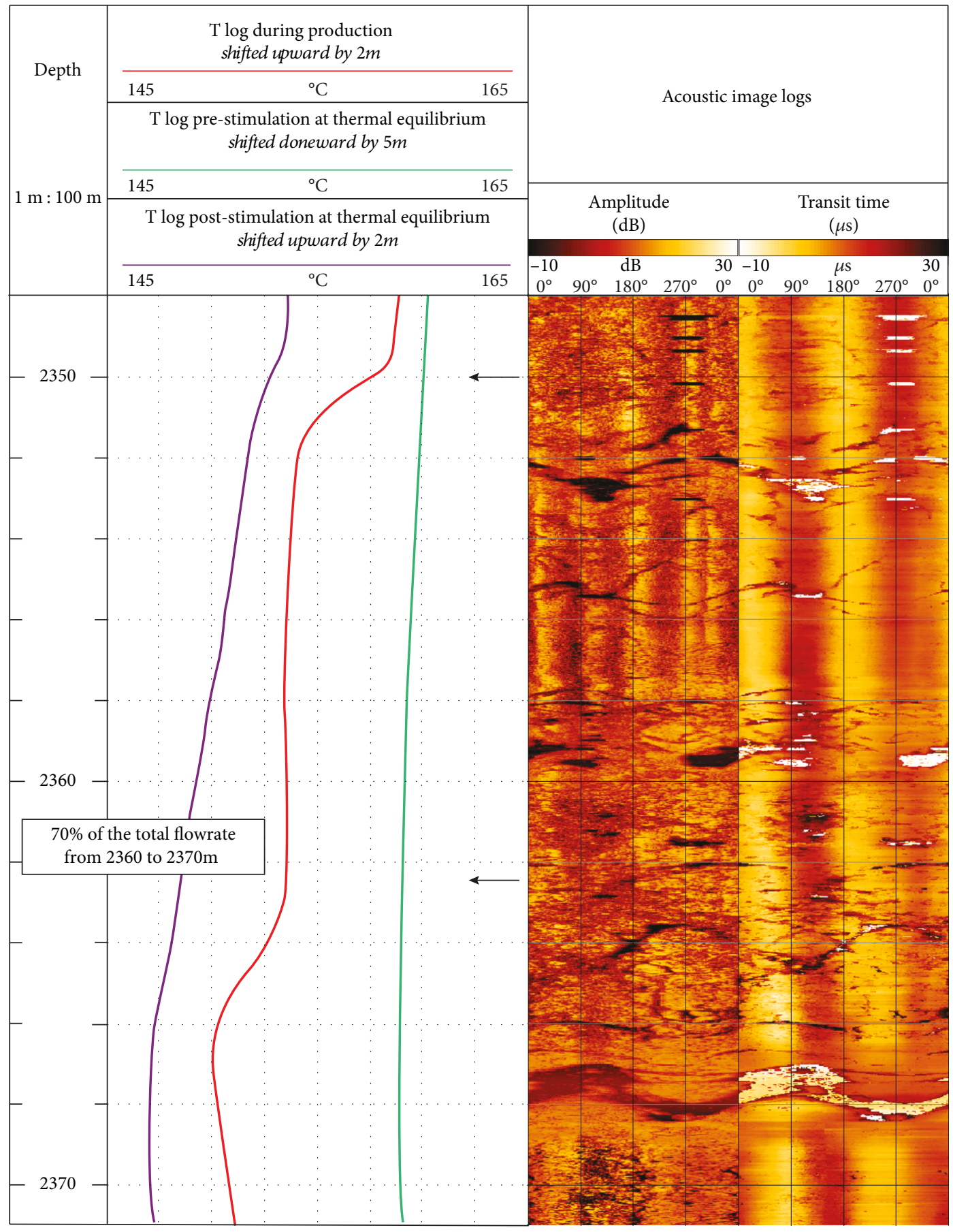

(c)

Figure 8: T logs obtained from well GRT-1 during production (Jan 2013, airlift production), at thermal equilibrium prestimulation (Apr 2013, four months after hydraulic tests) and poststimulation (Dec 2013, five months after hydraulic stimulation). Dotted lines indicate the gradient of the $\mathrm{T}$ logs during production (red) and poststimulation (purple). $\mathrm{T}$ anomalies are associated with open fractures observed in acoustic image logs at (a) $2236 \mathrm{~m} \mathrm{MD}$, (b) $2345 \mathrm{~m} \mathrm{MD}$, and (c) $2368 \mathrm{~m} \mathrm{MD}$. Arrows indicate inflows of geothermal water through fractures. Depth is expressed in MD. T logs and flow logs were shifted manually to match anomalies with fracture zones.

the prestimulation log indicates a large negative $\mathrm{T}$ anomaly, whereas the poststimulation $\mathrm{T} \log$ indicates two negative anomalies that correspond with those observed during production (Figure 3).
4.2.3. GRT-2. Only one temperature log at thermal equilibrium was acquired in this well in September 2014. Two positive $\mathrm{T}$ anomalies are observed for GRT2-FZ1 and GRT2-FZ2 (Figure 4). These anomalies are the only positive 
ones observed in the well, but as they are observed at thermal equilibrium, without previous injection into the well, they are considered reliable. They indicate water inflows hotter than the surrounding rock formation. Unfortunately, the temperature of this water cannot be precisely calculated because flow logs and $\mathrm{T}$ logs acquired during production are not available. Both anomalies are associated with open fractures at the borehole scale, which mainly strike $\mathrm{N} 170^{\circ} \mathrm{E}$ and dip westward [16].

\section{Discussion}

5.1. Thermal Signature of Permeable FZs. GPK1-FZ4 corresponds to the first inflow of water into the well and thus marks the beginning of thermal convection. The first inflow of water into the well is at $148^{\circ} \mathrm{C}$ through a fracture at $3496 \mathrm{~m} \mathrm{MD}$ (Figure 7). The negative anomaly in the production $\mathrm{T} \log$ is explained by an inflow of water colder than the deeper reservoir during production. The positive anomaly described above is interpreted as the inflow of water from a fracture at $3489 \mathrm{~m} \mathrm{MD}$, which is hotter $\left(150^{\circ} \mathrm{C}\right)$ than water from the fracture at $3496 \mathrm{~m} \mathrm{MD}\left(148^{\circ} \mathrm{C}\right)$. At thermal equilibrium, GPK1-FZ4 is associated with a negative anomaly because the water inflows have temperatures of $148^{\circ} \mathrm{C}$ and $150^{\circ} \mathrm{C}$ and are probably colder than the temperature of the deep granite at equilibrium (Figure 2).

GRT1-FZ1 also corresponds to the first inflow of water into the well and thus to the beginning of thermal convection. Positive $\mathrm{T}$ anomalies are observed in the bottom part of the FZ at 2365 and $2350 \mathrm{~m} \mathrm{MD}$ because geothermal water that comes from the fractures is hotter than the water coming from the underlying reservoir (Figure 8(c)). At thermal equilibrium, these hot water inflows are no longer observed, but the negative $\mathrm{T}$ anomaly does not suggest that hot water does not circulate. This means that the circulating water is probably colder than the reservoir at equilibrium. These fractures correlate with a flow anomaly. However, T anomalies during production at $2341 \mathrm{~m} \mathrm{MD}$ and $2235 \mathrm{~m} \mathrm{MD}$ indicate inflows of water colder than the mix of water below, a trend not seen in the flow $\log$ (Figures $8(\mathrm{a})$ and $8(\mathrm{~b})$ ). The $\mathrm{T}$ anomaly at $2231 \mathrm{~m} \mathrm{MD}$ is associated with an FZ enhanced after stimulation at $2236 \mathrm{~m} \mathrm{MD}$ because it is associated with a negative $\mathrm{T}$ anomaly in the poststimulation $\mathrm{T} \log$ (Figure 8(a)).

GRT2-FZ1 and GRT2-FZ2 exhibit the only two positive $\mathrm{T}$ anomalies at equilibrium observed in the wells of Rittershoffen. Positive T anomalies are probably less common than negative $\mathrm{T}$ anomalies at equilibrium because the reservoir at equilibrium is generally hotter than the circulating water. Fractures are direct paths for cold mud or water during drilling and hydraulic operations and thus cool faster than the rest of the rock formation. The greater the quantity of cold water that is injected, the fewer positive anomalies visible. Because well GRT-2 was not stimulated, positive anomalies are probably more common in that well than in the stimulated well GRT-1 and GPK-1.

As observed by Evans et al. [14], temperature flux and geothermal fluid flow are intimately linked. $\mathrm{T}$ logs are better tools than flow logs for examining water circulation because $\mathrm{T}$ logs are more sensitive to small water inflows than flow logs, which require massive water inflow to produce an observable modification in the rotation speed of the helix. However, the estimation of the absolute water temperature circulating in a fracture requires a reliable associated flow $\log$, which is often not available.

5.2. Water Circulation through Permeable FZs. Based on $\mathrm{T}$ and flow logs, most of the water circulation in the wells occurs in the first hundreds of meters of the granitic basement, where a high density of permeable FZs is observed: in the first 500 meters of the Soultz basement (1400 to $2100 \mathrm{~m}$ MD in GPK-1) and in the first 200 meters of the Rittershoffen basement (2200 to $2400 \mathrm{~m} \mathrm{MD}$ in GRT-1 and 2500 to $2800 \mathrm{~m}$ MD (i.e., 2200 to $2400 \mathrm{~m}$ TVD) in the deviated well GRT-2) (Figures 2-4). The partially open fractures are several centimeters wide inside the FZs and are probably interconnected to each other over short distances, leading to a rather complex 3D organization that has channelized the water circulation $[45,46]$. Inside a permeable $\mathrm{FZ}$, geothermal water can circulate at different temperatures through different partially open fractures, representing multichannel pathways for geothermal fluids, as observed in GPK-1, where the water coming from the upper fracture is hotter (Figure 7). In this case, water coming from fractures less than $10 \mathrm{~m}$ apart circulates at different temperatures, which is surprising because circulations coming from narrow fractures should reach a state of equilibrium and a homogeneous temperature. Water may circulate through the FZs too fast to reach equilibrium. From the dataset presented in this article, the velocity and direction of these circulations cannot be determined.

The orientations and dips of the fractures cannot be linked to the polarity of the $\mathrm{T}$ anomalies at equilibrium (Figure 6). Negative $\mathrm{T}$ anomalies at equilibrium are observed more often than positive ones in the Soultz and Rittershoffen wells, but the negative anomalies are linked to the contrast between the temperature of the fluid circulating through the FZs and the temperature of the reservoir at equilibrium, which is generally hotter than the circulating water. During production, a positive $\mathrm{T}$ anomaly indicates an inflow of water hotter than the mix of water circulating below (Figure 9). At equilibrium, this anomaly could be positive if the geothermal water coming from the fracture is hotter than the surrounding rock formation or negative if the geothermal water is colder than the surrounding rock formation. T logs acquired during production are representative of the mix of water present during circulation, whereas $\mathrm{T}$ logs at thermal equilibrium reflect the temperature of the water leaching through the FZs relative to the temperature of the surrounding rock formations.

Contrary to the interpretation proposed by Genter et al. [15], the negative $\mathrm{T}$ anomalies in $\mathrm{T}$ logs at equilibrium are not a result of cooling of the FZs but only indicate that the circulation of water is colder than the surrounding formation. However, equilibrium could be difficult to identify depending on the volume of cold water previously injected and the time since the last injection.

The recurrence of negative anomalies could also be influenced by hydrothermal alteration (Figure 9). As modeled by Gentier et al. [52], during cold injection, thermal 


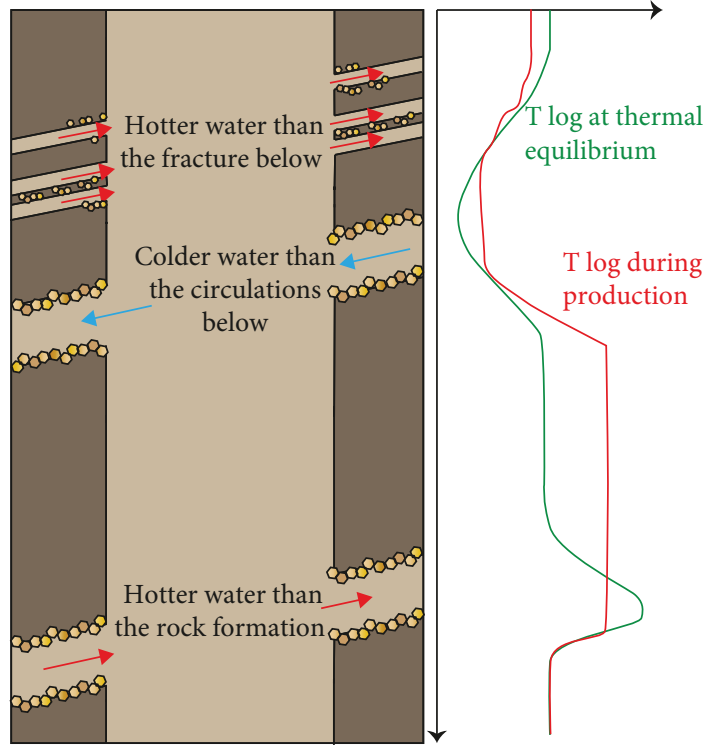

Figure 9: Conceptual model of fluid circulation in an FZ partly plugged with quartz and illite and the associated $\mathrm{T}$ anomalies measured during production and at thermal equilibrium.

microcracking of quartz within the FZ is observed, which creates preferential flow paths and thus leads to preferential cooling in these fractures. All permeable fractures are associated with quartz veins, which could enhance the thermal effect of cold reinjection through the FZs (Figures 2-4). Moreover, Tung et al. [53] and Alevizos et al. [54] suggested that occurrences of illite could enhance fault creeping, which can release fluid and trigger endothermic chemical reactions. In the case of GPK-1, Sausse et al. [33] identified the correlation between GPK1-FZ4 and the fault zone imaged in the reservoir. The influence of clay minerals, particularly illite, on the fault movements at Soultz was already proposed by Meller et al. [49]. In the case of GRT-1 and GRT-2, preliminary geometrical modeling suggests a possible correlation between GRT1-FZ1 and GRT2-FZ2 and a fault zone imaged in the reservoir $[7,16]$. The influence of these endothermic reactions on permeable FZs and the associated $\mathrm{T}$ anomalies should be investigated in further studies.

\section{Concluding Remarks}

In this study, a network of permeable FZs was identified in well GPK-1 at Soultz and wells GRT-1 and GRT-2 at Rittershoffen based on the reinterpretation of $\mathrm{T}$ logs obtained during production and at thermal equilibrium; these $\mathrm{T}$ logs were correlated with permeability indicators measured during drilling operations, acoustic image logs, and flow logs obtained during hydraulic tests. All permeable FZs present similar characteristics as follows:

(1) They are composed of $\mathrm{cm}$ thick fractures partly filled by quartz

(2) They are associated with T anomalies during production and/or at thermal equilibrium
This study presents a unique dataset of $\mathrm{T}$ logs and associated flow logs (if available) acquired during production and at thermal equilibrium at different times in well histories. $\mathrm{T}$ logs are useful and inexpensive tools for the localization of permeable FZs because they are more sensitive to small water inflows into wells than flow logs. Moreover, the comparison of $\mathrm{T}$ logs acquired in production and at thermal equilibrium provides a new interpretation of temperature anomalies. Based on these data, the temperature of water coming from partially open fractures was estimated. The study shows that geothermal water could circulate at different temperatures and in different fractures a few meters apart within the same FZ, which suggests a new interpretation of $\mathrm{T}$ anomalies. At temperature equilibrium, $\mathrm{T}$ anomalies are positive or negative with respect to the temperature of the surrounding rock formations. Because the surrounding formations are often hotter than the fractures, which are direct paths for fluid and thus cool faster than the surrounding rocks, negative anomalies are more often observed than positive ones. The nature of secondary deposits could also enhance the cooling effect observed in the T logs. In contrast, during production, anomalies are positive or negative with respect to the mix of water circulating below the fracture and not with respect to the surrounding formation. Therefore, anomaly polarity could change over time depending on the equilibrium state.

\section{Data Availability}

Please contact ES-Géothermie for data requests at geothermie@es.fr.

\section{Conflicts of Interest}

The authors declare that there are no conflicts of interest regarding the publication of this paper.

\section{Acknowledgments}

This work received funding from the European Union's Horizon 2020 research and innovation programme under grant agreement no. 792037 (MEET project). The study was partly funded by ADEME (French Agency of Energy and Environment) in the framework of the DEEP-EM project. The authors acknowledge the GEIE EMC and ECOGI for providing the data. The authors appreciate the helpful and constructive remarks of the two anonymous reviewers and the lead guest editor of this special issue, Dr Fabrizio Agosta.

\section{References}

[1] P. Baillieux, E. Schill, J.-B. Edel, and G. Mauri, "Localization of temperature anomalies in the Upper Rhine Graben: insights from geophysics and neotectonic activity," International Geology Review, vol. 55, no. 14, pp. 1744-1762, 2013.

[2] Y. Benderitter and P. Elsass, "Structural control of deep fluid circulation at the Soultz HDR site, France: a review, France," Geothermal Science and Technology, vol. 4, pp. 227-237, 1995.

[3] D. Pribnow and C. Clauser, "Heat and fluid flow at the Soultz Hot Dry Rock system in the Rhine Graben," in Proceedings of 
World Geothermal Congress 2000, Kyushu - Tohoku, Japan, 2000.

[4] D. Pribnow and R. Schellschmidt, "Thermal tracking of upper crustal fluid flow in the Rhine Graben," Geophysical Research Letters, vol. 27, no. 13, pp. 1957-1960, 2000.

[5] D. Bächler, T. Kohl, and L. Rybach, "Impact of graben-parallel faults on hydrothermal convection-Rhine Graben case study," Physics and Chemistry of the Earth, vol. 28, no. 9-11, pp. 431441, 2003.

[6] P. Baillieux, E. Schill, Y. Abdelfettah, and C. Dezayes, "Possible natural fluid pathways from gravity pseudo-tomography in the geothermal fields of northern Alsace (Upper Rhine Graben)," Geothermal Energy, vol. 2, no. 1, 2014.

[7] C. Baujard, A. Genter, E. Dalmais et al., "Hydrothermal characterization of wells GRT-1 and GRT-2 in Rittershoffen, France: implications on the understanding of natural flow systems in the Rhine graben," Geothermics, vol. 65, pp. 255-268, 2017.

[8] J. Baumgärtner and C. Lerch, "Geothermal 2.0: the Insheim geothermal power plant. The second generation of geothermal power plants in the Upper Rhine Graben," in Proceedings of third European geothermal review, Mainz, Germany, 2013.

[9] J. Baumgärtner, D. Teza, T. Hettkamp, G. Homeier, R. Baria, and S. Michelet, "Electricity production from hot rocks," in Proceedings of World Geothermal Congress 2005, Antalya, Turkey, 2005.

[10] A. Genter, C. Baujard, N. Cuenot et al., "Geology, geophysics and geochemistry in the Upper Rhine Graben: the frame for geothermal energy use," in Proceedings of European Geothermal Congress 2016, Strasbourg, France, 2016.

[11] T. Hettkamp, J. Baumgärtner, D. Teza, and C. Lerch, "Experiences from 5 years operation in Landau," in Proceedings of Third European Geothermal Review, Mainz, Germany, 2013.

[12] J. Vidal and A. Genter, "Overview of naturally permeable fractured reservoirs in the central and southern Upper Rhine Graben: insights from geothermal wells," Geothermics, vol. 74, pp. 57-73, 2018.

[13] C. Dezayes, A. Genter, and B. Valley, "Structure of the low permeable naturally fractured geothermal reservoir at Soultz," Comptes Rendus Geoscience, vol. 342, no. 7-8, pp. 517-530, 2010.

[14] K. F. Evans, A. Genter, and J. Sausse, "Permeability creation and damage due to massive fluid injections into granite at 3.5 $\mathrm{km}$ at Soultz: 1. Borehole observations," Journal of Geophysical Research: Solid Earth, vol. 110, no. B4, 2005.

[15] A. Genter, K. Evans, N. Cuenot, D. Fritsch, and B. Sanjuan, "Contribution of the exploration of deep crystalline fractured reservoir of Soultz to the knowledge of enhanced geothermal systems (EGS)," Comptes Rendus Geoscience, vol. 342, no. 78, pp. 502-516, 2010.

[16] J. Vidal, A. Genter, and F. Chopin, "Permeable fracture zones in the hard rocks of the geothermal reservoir at Rittershoffen, France," Journal of Geophysical Research: Solid Earth, vol. 122, no. 7, pp. 4864-4887, 2017.

[17] C. A. Barton, M. D. Zoback, and D. Moos, "Fluid flow along potentially active faults in crystalline rock," Geology, vol. 23, no. 8, pp. 683-686, 1995.

[18] J. Bradford, J. McLennan, J. Moore et al., "Recent developments at the Raft River geothermal field," in Proceedings of Thirty-Eighth Workshop on Geothermal Reservoir Engineering. Stanford University, California, USA, 2013.
[19] A. Mas, D. Guisseau, P. Patrier Mas et al., "Clay minerals related to the hydrothermal activity of the Bouillante geothermal field (Guadeloupe)," Journal of Volcanology and Geothermal Research, vol. 158, no. 3-4, pp. 380-400, 2006.

[20] C. Le Carlier, J.-J. Royer, and E. L. Flores, "Convetive heat transfer at the Soultz-sous-Forets geothermal site: implications for oil potential," First Break, vol. 12, no. 1285, 1994.

[21] V. Magnenet, C. Fond, A. Genter, and J. Schmittbuhl, "Twodimensional THM modelling of the large scale natural hydrothermal circulation at Soultz-sous-Forêts," Geothermal Energy, vol. 2, no. 1, 2014.

[22] S. Bellani, A. Brogi, A. Lazzarotto, D. Liotta, and G. Ranalli, "Heat flow, deep temperatures and extensional structures in the Larderello geothermal field (Italy): constraints on geothermal fluid flow," Journal of Volcanology and Geothermal Research, vol. 132, no. 1, pp. 15-29, 2004.

[23] D. Curewitz and J. A. Karson, "Structural settings of hydrothermal outflow: fracture permeability maintained by fault propagation and interaction," Journal of Volcanology and Geothermal Research, vol. 79, no. 3-4, pp. 149-168, 1997.

[24] N. C. Davatzes and S. H. Hickman, "Controls on faulthosted fluid flow; preliminary results from the Coso geothermal field, CA," in Geothermal Resources Council Transactions, pp. 343-348, Geothermal Resources Council, Davis, California,, 2005.

[25] J. E. Faulds and N. H. Hinz, "Favorable tectonic and structural settings of geothermal systems in the Great Basin region, Western USA: proxies for discovering blind geothermal systems," in Proceedings of World Geothermal Congress 2015, Melbourne, Australia, 2015.

[26] C. Dezayes, A. Genter, and S. Gentier, Deep geothermal energy in Western Europe: the Soultz Project - Final Report (open file no. BRGM/RP-54227-Fr), BRGM, Orléans, France, 2005.

[27] A. Gérard, A. Genter, T. Kohl, P. Lutz, P. Rose, and F. Rummel, "The deep EGS (enhanced geothermal system) project at Soultz-sous-Forêts (Alsace, France)," Geothermics, vol. 35, no. 5-6, pp. 473-483, 2006.

[28] B. Sanjuan, R. Millot, C. Dezayes, and M. Brach, "Main characteristics of the deep geothermal brine $(5 \mathrm{~km})$ at Soultz-sousForêts (France) determined using geochemical and tracer test data," Comptes Rendus Geoscience, vol. 342, no. 7-8, pp. 546559, 2010.

[29] B. Sanjuan, J. Scheiber, F. Gal, S. Touzelet, A. Genter, and G. Villadangos, "Interwell chemical tracer testing at the Rittershoffen site (Alsace, France)," in Proceedings of European Geothermal Congress 2016, Strasbourg, France, 2016.

[30] A. Genter and H. Traineau, "Analysis of macroscopic fractures in granite in the HDR geothermal well EPS-1, Soultz-sousForêts, France," Journal of Volcanology and Geothermal Research, vol. 72, no. 1-2, pp. 121-141, 1996.

[31] O. Lengliné, M. Boubacar, and J. Schmittbuhl, "Seismicity related to the hydraulic stimulation of GRT1, Rittershoffen, France," Geophysical Journal International, vol. 208, no. 3, pp. 1704-1715, 2017.

[32] J. Place, M. Diraison, C. Naville, Y. Géraud, M. Schaming, and C. Dezayes, "Decoupling of deformation in the Upper Rhine Graben sediments. Seismic reflection and diffraction on 3component vertical seismic profiling (Soultz-sous-Forêts area)," Comptes Rendus Geoscience, vol. 342, no. 7-8, pp. $575-586,2010$. 
[33] J. Sausse, C. Dezayes, L. Dorbath, A. Genter, and J. Place, “3D model of fracture zones at Soultz-sous-Forêts based on geological data, image logs, induced microseismicity and vertical seismic profiles," Comptes Rendus Geoscience, vol. 342, no. 7-8, pp. 531-545, 2010.

[34] S. Gentier, X. Rachez, T. D. T. Ngoc, M. Peter-Borie, and C. Souque, "3D flow modelling of the medium-term circulation test performed in the deep geothermal site of Soultzsous-Forêts (France)," in Proceedings of World Geothermal Congress 2010, Kyushu - Tohoku, Japan, 2010.

[35] A. Genter, C. Castaing, C. Dezayes, H. Tenzer, H. Traineau, and T. Villemin, "Comparative analysis of direct (core) and indirect (borehole imaging tools) collection of fracture data in the Hot Dry Rock Soultz reservoir (France)," Journal of Geophysical Research, vol. 102, no. B7, pp. 15419-15431, 1997.

[36] J. Vidal, A. Genter, F. Chopin, and E. Dalmais, "Natural fractures and permeability at the geothermal site Rittershoffen, France," in Proceedings of European Geothermal Congress 2016, Strasbourg, France, 2016.

[37] H. Traineau, A. Genter, J.-P. Cautru, H. Fabriol, and P. Chèvremont, "Petrography of the granite massif from drill cutting analysis and well log interpretation in the geothermal HDR borehole GPK-1 (Soultz, Alsace, France)," in Geothermal Energy in Europe-The Soultz Hot Dry Rock Project, J. C. Bresee, Ed., pp. 1-29, Gordon and Breach Science Publishers S.A., Montreux, Switzerland, 1992.

[38] A. Genter, H. Traineau, B. Ledésert, B. Bourgine, and S. Gentier, "Over 10 years of geological investigations within the HDR Soultz project, France," in Proceedings of World Geothermal Congress 2000, Kyushu - Tohoku, Japan, 2000.

[39] M. P. Smith, V. Savary, B. W. D. Yardley, J. W. Valley, J. J. Royer, and M. Dubois, "The evolution of the deep flow regime at Soultz-sous-Forêts, Rhine Graben, eastern France: evidence from a composite quartz vein," Journal of Geophysical Research: Solid Earth, vol. 103, no. B11, pp. 27223-27237, 1998.

[40] B. Ledésert, G. Berger, A. Meunier, A. Genter, and A. Bouchet, "Diagenetic-type reactions related to hydrothermal alteration in the Soultz-sous-Forêts Granite, France," European Journal of Mineralogy, vol. 11, no. 4, pp. 731-742, 1999.

[41] C. Glaas, A. Genter, J. F. Girard, P. Patrier, and J. Vidal, "How do the geological and geophysical signatures of permeable fractures in granitic basement evolve after long periods of natural circulation? Insights from the Rittershoffen geothermal wells (France)," Geothermal Energy, vol. 6, no. 1, p. 14, 2018.

[42] G. R. Hooijkaas, A. Genter, and C. Dezayes, "Deep-seated geology of the granite intrusions at the Soultz EGS site based on data from $5 \mathrm{~km}$-deep boreholes," Geothermics, vol. 35, no. 5-6, pp. 484-506, 2006.

[43] J. Vidal, P. Patrier, A. Genter et al., "Clay minerals related to the circulation of geothermal fluids in boreholes at Rittershoffen (Alsace, France)," Journal of Volcanology and Geothermal Research, vol. 349, pp. 192-204, 2018.

[44] J. Vidal, A. Genter, C. Glaas, R. Hehn, N. Cuenot, and C. Baujard, Temperature Signature of Permeable Fracture Zones in Geothermal Wells of Soultz-sous-Forêts in the Upper Rhine Graben, GRC Transactions, Reno, Nevada, USA, 2018.

[45] J. Sausse, C. Dezayes, A. Genter, and A. Bisset, "Characterization of fracture connectivity and fluid flow pathways derived from geological interpretation and 3D modelling of the deep seated EGS reservoir of Soultz (France)," in Proceedings of Thirty-Third Workshop on Geothermal Reservoir Engineering. Stanford University, California, USA, 2008.

[46] J. Sausse, M. Fourar, and A. Genter, "Permeability and alteration within the Soultz granite inferred from geophysical and flow log analysis," Geothermics, vol. 35, no. 5-6, pp. 544-560, 2006.

[47] L. Aquilina, M. Brach, J. C. Foucher, A. De Las Heras, and G. Braibant, Deepening of GPK-1 HDR Borehole 2000-3600 m (Soultz-sous-Forêts, France), Geochemical Monitoring of Drilling Fluids (open file no. R36619), BRGM, Orléans, France, 1993.

[48] F.-D. Vuataz, M. Brach, A. Criaud, and C. Fouillac, "Geochemical monitoring of drilling fluids: a powerful tool to forecast and detect formation waters," SPE Formation Evaluation, vol. 5, no. 2, pp. 177-184, 1990.

[49] C. Meller, A. Kontny, and T. Kohl, "Identification and characterization of hydrothermally altered zones in granite by combining synthetic clay content logs with magnetic mineralogical investigations of drilled rock cuttings," Geophysical Journal International, vol. 199, no. 1, pp. 465-479, 2014.

[50] M. Dubois, B. Ledésert, J. L. Potdevin, and S. Vançon, "Détermination des conditions de précipitation des carbonates dans une zone d'altération du granite de Soultz (soubassement du fossé Rhénan, France) : l'enregistrement des inclusions fluides," Comptes Rendus de l'Académie des Sciences - Series IIA - Earth and Planetary Science, vol. 331, no. 4, pp. 303309, 2000.

[51] R. Jung, "Hydraulic fracturing and hydraulic testing in the granitic section of borehole GPK-1, Soultz-sous-Forêts," in Geothermal Energy in Europe - The Soultz Hot Dry Rock Project, J. C. Bresee, Ed., pp. 149-198, Gordon and Breach Science Publishers S.A, Montreux, Switzerland, 1992.

[52] S. Gentier, A. Hosni, C. Dezayes, and A. Genter, Projet GEFRAC: modélisation du comportement hydro-thermomécanique des milieux fracturés (module 1) (Open file report No. BRGM/RP-52702-FR), BRGM, 2004.

[53] R. Tung, T. Poulet, M. Peters, M. Veveakis, and K. RegenauerLieb, "Explaining high permeability on localised fault zones through THMC feedbacks - a Soultz-sous-Forêts inspired approach," in Proceedings of 40th New Zealand Geothermal Workshop. Presented at the New Zealand Geothermal Workshop, Taupo, New Zealand, 2018.

[54] S. Alevizos, T. Poulet, and E. Veveakis, "Thermo-poromechanics of chemically active creeping faults. 1: theory and steady state considerations," Journal of Geophysical Research: Solid Earth, vol. 119, no. 6, pp. 4558-4582, 2014.

[55] GeORG Team, "EU-Projekt GeORG - Geoportal [WWW Document]," 2017, June 2017, http://www.geopotenziale.org/ home?lang=3.

[56] B. C. Valley and K. F. Evans, "Stress state at Soultz-sous-Forêts to $5 \mathrm{~km}$ depth from wellbore failure and hydraulic observations," in Proceedings of Thirty-Second Workshop on Geothermal Reservoir Engineering. Stanford University, California, USA, 2007.

[57] R. Hehn, A. Genter, J. Vidal, and C. Baujard, "Stress field rotation in the EGS well GRT-1 (Rittershoffen, France)," in Proceedings of European Geothermal Congress 2016, Strasbourg, France, 2016. 

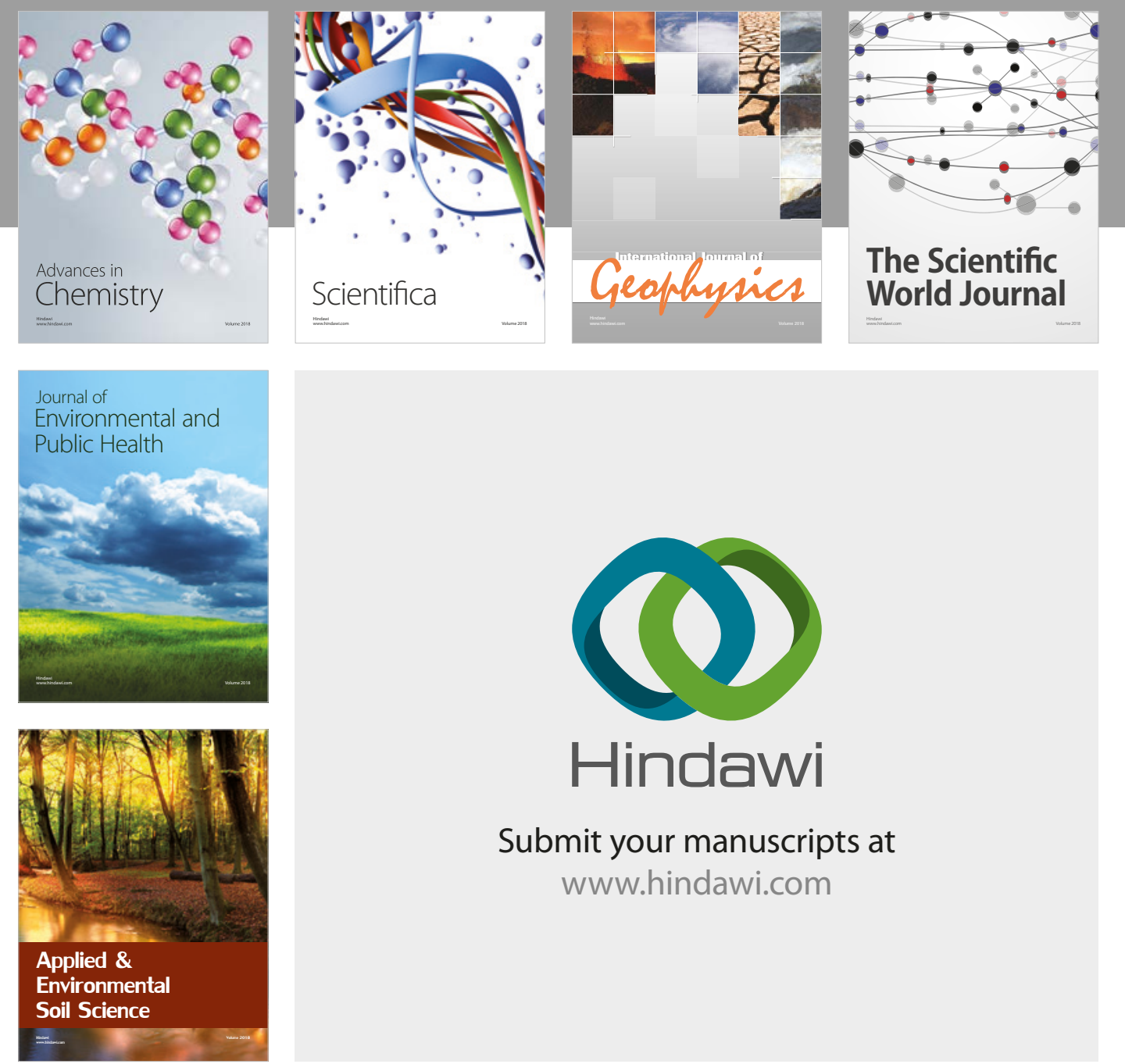

The Scientific

\section{World Journal}
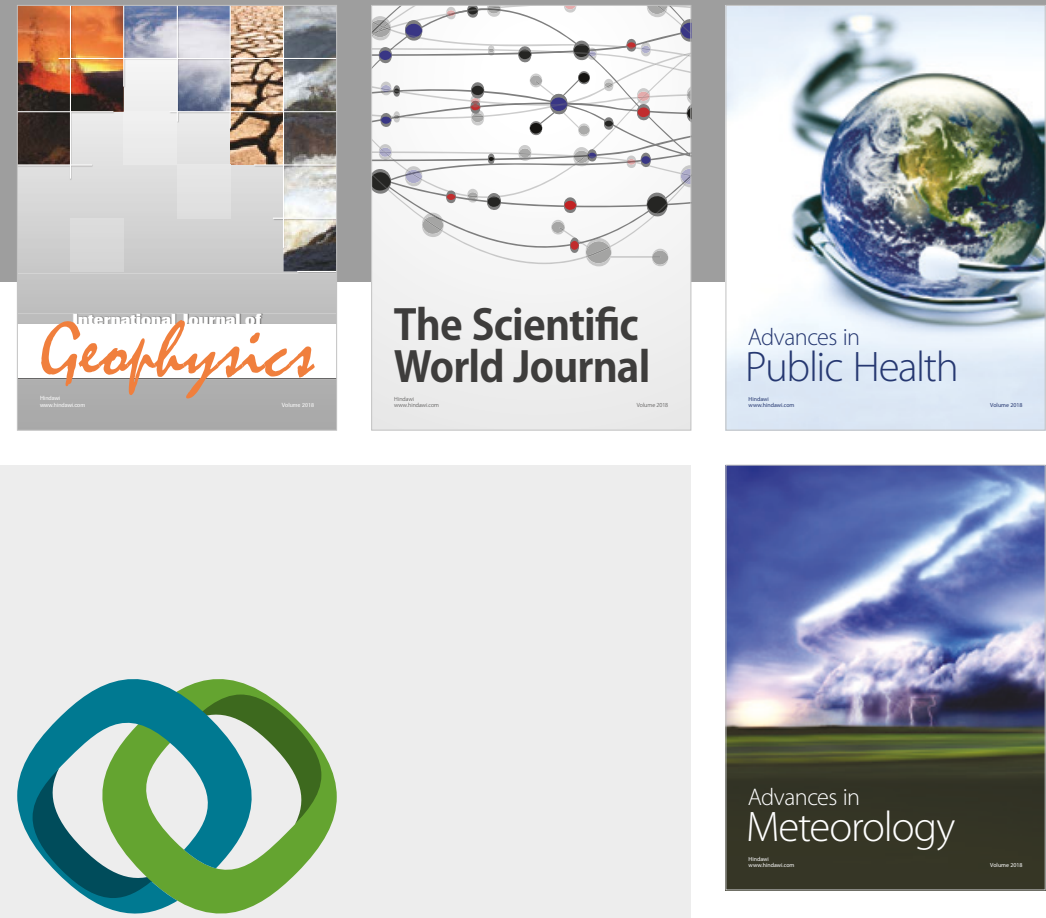

Advan

Public Health

\section{Hindawi}

Submit your manuscripts at

www.hindawi.com
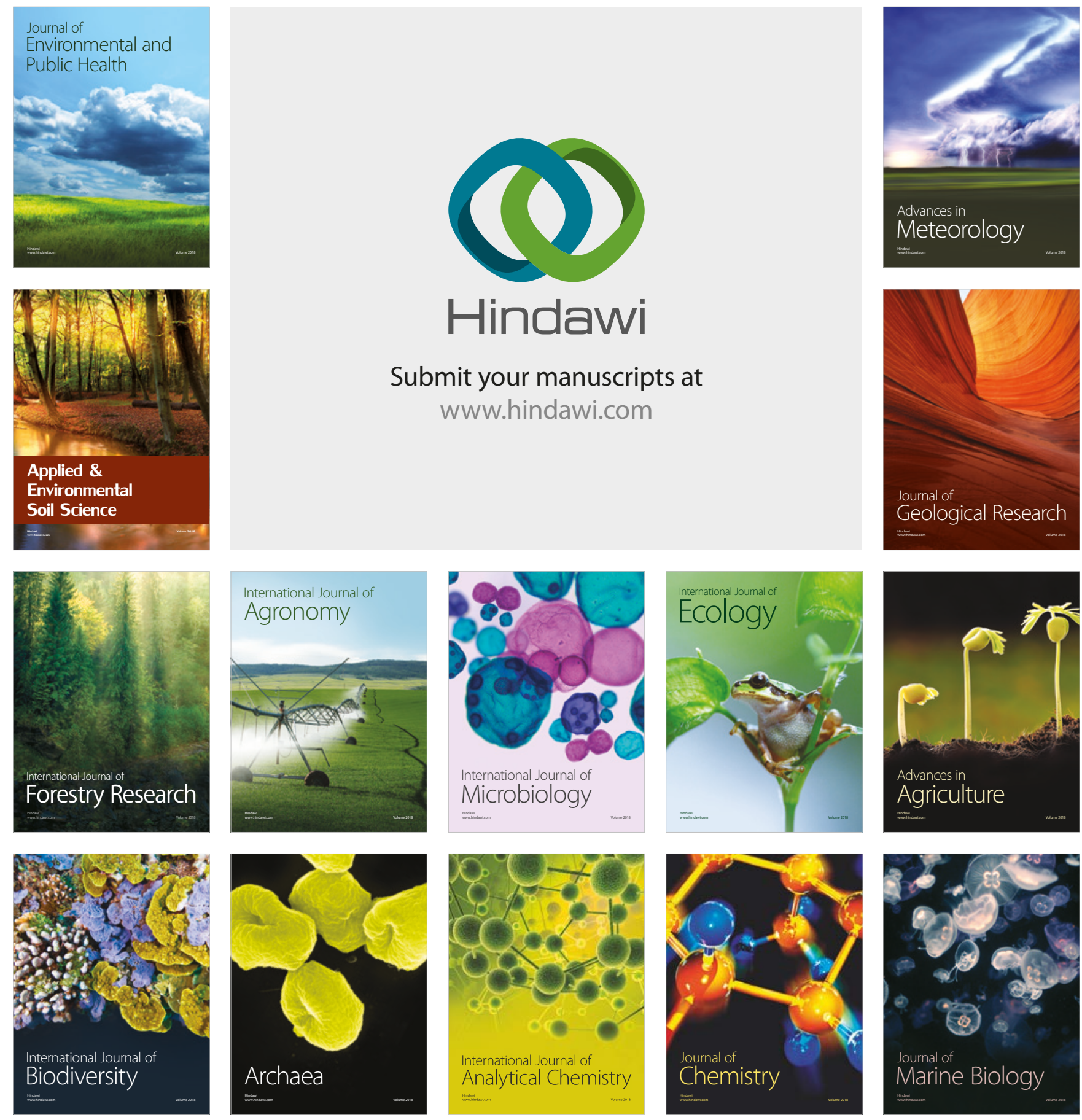